\title{
Building an EU identity: Policy development at the EU-level - An overview of the current state
}

\author{
JULIAN GRIMM \\ The University of Sydney \\ julian.grimm@me.com
}

\begin{abstract}
The EU has, belatedly perhaps, engaged with the issue of building an EU identity by setting up various initiatives aimed at building a sense of civic society across Europe and hence of greater citizen identification with the EU. This article analyses EU policy formulations from the 1970s through to the very different conditions of the past decade. It also discusses the process undertaken by the EU institutions in order to establish the levels to which and the ways in which its citizens understand and 'feel' themselves to be members of the EU on a personal and individual as well as social and cultural level, if at all. The aim of the article is to establish whether this is considered sufficient for the ongoing operation of the EU, or, if not, what is lacking.
\end{abstract}

Keywords: EU policies, EU identity, civic society, policy evaluation

\section{Introduction}

Over the past decade and a half, issues of identity have come to the fore in discussions of the state of the European Union, both within the organization and in academic and community discourse. Lack of identity here implies a perceived lack or insufficiency of self-identification in terms of the EU by the broad constituency of EU citizens, regardless of their national identities (Stanley, 2013, p. 5). While problems of 'democratic deficit' have been approached over this period in terms of strengthening of the EU Parliament and other relevant institutions, especially since Maastricht, a gap has become evident in the civic component of European citizens' self-identification in the wake of events such as the GFC, the refugee crisis, and the COVID crisis. EU citizens may identify broadly in cultural and historical terms as 'European' but this selfidentification appears to have failed to translate into political terms in the context of the second decade of the $21^{\text {st }}$ century (Delanty, 2019, p. 318; Walkenhorst, 2009, p. 1).

For the EU this has become a major issue. Since the late 1990s commentators have increasingly focused on civic rather than political aspects of EU functioning in order to explain the weakening in impetus towards an 'ever closer union' (Borneman \& Fowler, 1997, p. 487; Castano, 2004, p. 42; Cerutti \& Rudolph, 2001, p. 26; Delanty, 2003, p. 76). In response the EU has developed and implemented policies aimed at strengthening at grass roots level the civic sense of Europeanness (European 
Commission, 2012, p. 9ff; European Commission, 2014, p. 1ff; European Parliament, 2020, p. 26ff; Prutsch, 2017, p. 35ff).

This article will analyse EU policies regarding EU identity development, which aim to strengthen a civic sense of commitment to and identification in terms of the European Union. This work also intends to contribute to the considerable academic debate that has been generated over the past two decades.

\section{The European Union and Identity}

European citizens, spread across 27 EU member states and various other European countries, make up almost half a billion individual identities. In addition to personal, family and private individual identities, regional and national identities exist to constitute what is referred to as "Europe." The EU represents a large proportion of these groups. Such collective identities have formed over extensive periods of time and are complemented partly by additional, co-existing forms of collective identity such as supranational, transnational and cosmopolitan identities (Delanty, 2003, pp. 76, 85; Eurobarometer, 2018; Habermas, 2009, p. 90).

Academic debate has shown identity per se to be an evasive, notoriously intangible and variable concept, in particular with regard to collective forms such as supranational identity (Bruter, 2005, p. 3; Smith, 1992, p. 62). The EU Parliament in 2017 engaged with this ambiguous issue of "belonging" to both Europe and to the EU by differentiating between a cultural (European) and political (EU) identity, respectively (Prutsch, 2017, p. 15).

Originally primarily conceptualized as an economic space, the EU has developed dramatically into a deeper and closer union than merely economic collaboration. Since its foundation, the EU institutions have developed along three major lines to strengthen an emerging political identity: firstly, by using the economic collaboration post WWII between its six founding members to build and ensure peace in historically war-torn Europe; secondly, by basing membership on a set of developing criteria in terms of civil liberties and human values; and, thirdly, as a political-economic union generating high levels of well-being and value of life in the member states, at least during the initial years and with the post-1989 enlargement prior to the GFC in 2007/8. This economic-political union encompassed a dramatically enlarged membership of Western, Southern and Eastern European countries (Prutsch, Senior Administrator, Directorate-General for Internal Policies of the Union, European Parliament, 2020, interview).

A sense of belonging to Europe in this political sense, referred to here as an EU identity, has been statistically observed by European institutions and according to Eurobarometer has grown over time (Eurobarometer 2006, 2018, 2019). However, academic literature (Delanty, 2019, p. xxii; Tekiner, 2020, p. 2) and cetain policy documents of the EU itself (European Commission, 2012, p. 28; Prutsch, 2017, p. 5) have questioned the correlation between EU institutional development and 'bottomup' self-identification of citiziens as 'EUropeans'. In order to understand the amibiton of the EU to build a political EU identity, this article will in the following present and discuss key EU policy documents. 


\section{Overview of EU policy documents on EU identity}

The process of European integration started formally with the Treaties of Paris and Rome in the early 1950s, leading to the establishment of the European Coal and Steel and subsequent European Community (ECSC and EC). Collaboration among EC member countries led to a process of increased economic integration. Political leaders saw an increasing need to instrumentalise an emerging collective identity, which the EC referred to formally as "European identity" as early as 1973 in the Copenhagen Declaration. From the perspective of the political leadership of the time, such European identity was a result of continuous integration (European Communities, 1973, p. 119). Hence, cultural similarities of the citizens of then EC members were instrumentalised to create a shared belonging, through developed continuous integration.

The world order had also changed over this period: in terms of monetary policies, with the end of the Bretton Woods system and in terms of economic policies with an end of Keynesian interventionism. As a result, European political elites continued to focus on the path of integration and with that European identity as a primary recognition of the course forward (Tekiner, 2020, p. 3). The result of the Declaration on European Identity (European Communities, 1973, p. 119ff) was a reference to "responsibility towards the rest of the world", which created a hierarchy of identities hence was ideologically loaded (Stråth, 2002, p. 387). The intention was to "carry (...) the work further in the light of the progress made in the construction of a United Europe" (European Communities, 1973, p. 119). European identity was meant to create the backbone of identity for an emerging and continuous process of European integration.

At the same time, the declaration can be understood as an awareness that continuous integration does not automatically lead to a sufficiently strong rapprochement of citizens of member countries for them to act and think as European citizens. The intention was to actively promote European cultural identity, which was also called out as a proposal in the so-called Tindemans Report of 1976. The success of this is questionable. However, the introduction of European symbols such as the flag, an academic exchange program (Erasmus) and eventually the idea of European passports are recognized as positive reference points in the academic debate (Karlsson, 1999, p. 65).

This cultural Europeanism and national interventionism together with neo-Keynesian macroeconomics corresponded to the zeitgeist of the 1970s. The 1980s, however, were dominated by a growing neoliberalism in which European integration gained new momentum, spurred by its internal setup of a "pan-European tripartite order or corporatist bargaining" which positioned European identity regarding its core mission and purposes in line with emerging trends such as globalisation and deregulation (Străth, 2002, p. 389). As the EC grew in terms of member countries, its selfunderstanding also developed and strengthened in terms of how it presented itself to the world.

In the mid-1980s, the Community founded a 'Committee for a People's Europe' with the intention of promoting European identity further and the European Commission introduced some first cultural identity politics with a focus on shared cultural heritage among Europeans. European institutions have adopted certain shared or core values such as "respect for freedom, rights and dignity; rule of law, equality before the law, 
and political pluralism; separation of powers and democratic institutions; protection of minorities and respect for civil society" (Tekiner, 2020, p. 3). Some of these had already appeared in the Declaration on European Identity in 1973 (European Communities, 1973, p. 119). They have been used politically to create a narrative of a shared cultural belonging, which can be referred to as EU identity. Symbols introduced by the Commission Presidency such as a flag, an anthem and other elements are usually part of nation-building processes (Karlsson, 1999, p. 65), which seems to have been the intention of the fostering of European identity from a political perspective.

The establishment of the European Union under the Treaty of Maastricht in the early 1990 s represented a major leap forward in terms of EU identity with the constitution of the concept of European citizenship and European institutions acting on behalf of the people of Europe. In parallel, however, Euroscepticism increased and neither a culturalist strategy of building an EU identity nor additional elements of citizen identification through a shared currency, as part of the introduction of the European Monetary Union (EMU), seem to have made the citizens of European member states into fervent citizens of Europe (understood as the EU) (Tekiner, 2020, p. 4).

EU identity emerged as an approved research topic for the European Commission in the 1990s, in particular in the so-called Framework Programmes for Research and Technological Development. The intent has been to understand "how different processes of identification with the European Union and its integration project take shape and evolve over time, and how to reinforce solidarity among Europeans" (European Commission, 2012, p. 4). This indicates a clear awareness by European institutions for the need to gain some further understanding in this area with the help of EU-funded research, including the so-called "Horizon 2020" programme, the most recent Framework Programme for Research (2014-2020) and 20+ research projects "which have a bearing on processes of identity formation and identification with(in) Europe and the EU". These programs also serve as policy blueprint for "policy-makers in a wider range of domains at EU, national and local levels, from education and culture to migration and social policies" (European Commission, 2012, p. 4).

The review of the Framework Programmes concluded that two models of European identity formation can be differentiated: firstly, a 'culturalist' perspective, as "an orientation to Europe [which] derives fundamentally from core, established European values and their expression in public practices, most notably in governance", hence, citizens identify with Europe in a 'top down' way or identity stems from being exposed to symbols etc.; secondly, a 'structuralist' model as "an orientation to Europe [which] derives fundamentally from association with other Europeans (...) interacting with others” which is a 'bottom up' approach. (European Commission, 2012, p. 8).

With regard to a culturalist perspective, the European Commission sought to finalize the drafting of a 'New Narrative for Europe' document in 2014 by a group of "artists, intellectuals and scientists, and first and foremost citizens" with the intention of regaining confidence in Europe (European Commission, 2014, p. 1). This initiative was signed off by the European Parliament and the then President of the European Commission and was intended as a catalyst to understand Europe's "state of mind" to then be able to develop at some stage "a true and well-functioning political body in Europe" (European Commission, 2014, p. 1). Based on the concept of Europe as a shared cultural heritage, the narrative document defines Europe as a "moral and political responsibility" and as "an identity, an idea, an ideal" (European Commission, 
2014, p. 1) built around "shared values of peace, freedom, democracy and rule of law" and, according to the narrative statement, it has "been deeply embedded in the "raison d'être" of Europe" (European Commission, 2014, p. 2). Hence, as a political body, it encourages European citizens to "raise their voices to take part in the European public space of debate" (European Commission, 2014, p. 3). This same theme of "European political elites (...) attempting to add a transnational layer to existing national collective identities since the dawn of European integration" is outlined by research for the CULT Committee on European identity by the European Parliament. The research report also refers to "the assumption [by European institutions] that there is a need to engender a feeling of belonging to Europe that goes beyond the economic and institutional dimension" (Prutsch, 2017, p. 18).

This process of achieving "an official and normative declaration of identity" (Prutsch, 2017, p. 18) started in 1973 with the Copenhagen Declaration on European Identity. While no further statements have been published since then in regards to the level of prescriptiveness, certain topoi have emerged in the discourse of EU identity among EU political elites. These elites use the term Europen identity when they are in fact referring to an EU identity consisting of: firstly, a European heritage with "a common culture as the crucial element of European identity"; secondly, the two World Wars with their horrors and the resulting "momentum to set up 'Europe' as a supranational peace project"; and thirdly, "European integration itself, the historical achievements of which add to the legitimacy of the Union and are embodied in its official symbols" (ibid, p. 19).

The agenda of promoting an EU identity was catapulted to the forefront of EU politics at the beginning of the $21^{\text {st }}$ century, in particular as a result of "the failure of the ambitious "Constitution for Europe" project, epitomised by the rejection of the draft text in France and the Netherlands in the 2005 referendums (...) as an expression of growing public disenchantment with European (Union) 'high politics"'(ibid). This, according to the European Parliament, "proved that there was a need for a decisive political action going beyond what mainly been symbolic politics" (ibid, p. 19f). Concrete outcomes of this newly emerging awareness were a "detailed qualitative study by the European Commission on the Europeans, Culture and Cultural Values" in 2005 and a new programme with the name 'Europe for Citizens' by the European Parliament and the Council first set up for 2007 to 2013 with a "legal framework to support a wide range of activities and organisations". These were meant to promote "active European citizenship", which the European Parliament defined as "the involvement of citizens and civil society organisations in the process of European integration with a view to developing a sense of identification" (ibid, p. 20).

The programme focused on the following objectives:

- "Giving citizens the opportunity to interact and participate in constructing an ever closer Europe, which is democratic and world-oriented, united and enrichted throuhg its cultural diversity, thus developing citizenship off the European Union;

- Developing a sense of European identity, based on common values, history and culture;

- Fostering a sense of ownership of the European Union among its citizens; 
- Enhancing tolerance and mutual understanding between European citizens respecting and promoting cultural and linguistic diversity, while contributing to interculturla dialogue" (ibid, p. 20)

All this was meant to be achieved through exchange, debate, reflection, i.e. "civic engagement and active citizenship, which were considered to be key vehicles for promoting (European) identity". It also represented an additional focus to perceive Europe and its idea not only as a cultural but, first and foremost, as a political community "made up of responsible and active citizens". While "Citizenship of the Union" as a concept was introduced with the Treaty of Maastricht in 1992, the Lisbon Treaty underlined this understanding and also introduced "a new form of public participation for European citizens through the "citizens' initiative", offering EU citizens the chance to participate directly in the development of EU policies" (ibid, p. 21).

The objectives and initiatives that were introduced "not only marked the internalisation of the politico-theoretical concept of 'constitutional patriotism' by the European Union, but also the gradual shift from a top-down to bottom-up model of identiy building" (ibid, p. 21). Instead of political elites defining identity, as was done previously, inlcuding with the Cophenhagen Declaration on European Identity, the focus has shifted to citizens and their individual action. This was a lenghty learning process for European political elites which culminated in the rejection of the EU Constitution in 2005 as until then the focus had always been on a top-down agenda which resembled nation-building activities.

The importance of the concept of citizenship continued to be the focus of EU identity politics, including in the subsequent Europe for Citizens Programme 2014-2020. However, a strong shift has occurred towards the idea of 'historical remembrance', which has become more important while the term 'identity' has almost been removed from the programme. According to the report by the European Parliament, this can be understood as a "growing disinterest if not discomfort towards '(European) identity' as an explicit political objective at EU level and especially among Member States, with the Council serving as their mouthpiece” (ibid, p. 22).

Various crises in Europe and among the member states of the EU itself have occurred, i.e., the financial and refugree crises, Brexit, implications of the 2016 US election and the political-institutional crisis of the EU. These crises have led to questions regarding the ability of the EU to tackle any outstanding issues as it would otherise endanger its political legitimacy, which "is intrinsically linked to the question of what holds this political construct sui generis together and creates a sense of unity among its citizens" (ibid, p. 22). As "the political, economic, and monetary integration of the Union kept resting on a cultural sense of belonging to Europe" (Tekiner, 2020, p. 4), in times of crises as recently experienced in Europe, the bond between Europeans becomes ruptured as the desired EU identity is only based on a fragile feeling of belonging, of identifying politically as a European citizen in the making.

For a long time, it remained questionable how the financial repercussions and other consequences of the above mentioned crises would be shared in the European context. The repercussions of this have now become a contentious and controversial debate among the different camps of collective identity on a European level between a supranational approach with sharing risk and costs between all EU members and a national approach with individual country approaches. Given the interconnectedness 
of EU member countries on a mobility level with the Schengen agreement, economically with a shared market and monetarily with its currency union, national solutions have become inadequate to solve supranational problems.

European institutions are aware of this problematic situation in which "some deny the need for a 'European identity' altogether [while] others deem the strengthening of such an identity the only way forward". The future direction of the EU has become an open conflict and the question of "how trans-European identity could and should be dealt with in the future has become a virtually impossible task". Hence, the status quo of EU identity in the sense of "identification with Europe and the EU continues to be very much in the making, and relatively weak in comparison with national identities" (Prutsch, 2017, p. 23).

As a means of overcoming this gridlock, the European Commission is seeking to promote the European public and cultural space with its Horizon 2020 strategy and aims to "reduce the gap between institutions and citizens - through better understanding, analysis and practical solutions - in order to build a more trustful European society" (European Commission, 2017a, p. 6). It is assumed that the "resilience and cohesion of European societies are strongly conditioned by beliefs and identities, as well as by collective representations and constructions of past and present realities and expectations about the future". The European Commission still has not given up on its mantra of a narrative for Europe by hypothesizing that research "in the humanities and social sciences is well-placed for making important contributions to creating a new narrative for Europe by studying the drivers of and obstacles to the emergence of a European public sphere and a European cultural space". Accordingly, the European Commission wants to encourage a "better understanding of Europe's cultural, social unity and diversity of its past will inform the reflection about present challenges / opportunities and help to find solutions for shaping Europe's future" (European Commission, 2017a, p. 84).

According to the European Commission, a European cultural, political and economic identity has existed for centuries (European Commission, 2017a, p. 100) which as a claim rather seems to follow the logic of creating a narrative of shared belonging than basing it on actual events (Delanty, 2019, p. 15). Linking European identity to integration is considered (or: seen as) challenging due to the culturally diverse underlying values and memories which can underline difference and separateness. With the self-diagnosis of an incomplete level of European integration but growing "xenophobia, extremism, ethnic conflict, Euro-scepticism and the revival of the NorthSouth and East-West divides, as well as electoral apathy and disenchantment" (European Commission, 2017a, p. 100), even a reference to a distinct European space as per European Commission does not solve the issues of a lack of further integration. Hence, European institutions encourage modelling of ideal types of linking culture and integration to gain a better understanding of the phenomenon.

\section{EU Policies and Operations: Outcomes}

Since the origins of the EU, political elites have called on a narrative of a peace-building project in a war-torn continent as a point of reference and identification for European citizens, initially as an economic and then also increasingly as a political union. As outlined earlier, this sense of belonging was expanded in the 1970 s with the Declaration of Copenhagen normalising and determining what EU identity (as referred 
to as European identity by its authors) was meant to imply. This top-down approach was intended to guide citizens of member countries in a prescriptive way as to what constituted European identity.

Despite a long process of integration measures, including the Treaty of Maastricht with the formation of the EU and the Schengen Area and later the EMU, European institutions cannot be said to have succeeded in inculcating a sense of shared European belonging, despite all their efforts. The result of an increasingly negative attitude of EU citizens towards the political union could not be ignored or denied any longer by the rejection of the EU constitution by referendums in France and the Netherlands, two founding members of the earliest collaboration, the European Coal and Steel Community.

The 2014 New Narrative for Europe initiative provides an example of how top-down EU policies to create a transnational European memory by tapping into the cultural heritage o Europe, framing a narrative of a shared European history, has failed.According to Kaiser (2015, p. 364), the final document "illustrates the strict limits of such top-down cultural engineering in a transnational polity like the EU." While narratives have been used over centuries, often by cultural elites for the sake of political movements or nation-building (cf. Italy, Germany) and also by historians in the form of a national identity and nationhood (Berger \& Lorenz, 2010, p. 3ff), the Narrative for Europe project can be seen "as an express attempt by individual members of the EU's political and bureaucratic elites to motivate members from a partly transnationally constituted cultural milieu to frame a new narrative for Europe and the EU" (Kaiser, 2015, p. 365). It outlines how ineffective "bureaucratic initiatives [are] in influencing collective memory in a polity with partly transnationally constituted elites, but without a common public sphere for disseminating narratives consistently across space and time" (Kaiser, 2015, p. 366).

Major efforts to boost EU identity have ceased in the wake of the GFC and the monetary crisis. Then, eventually, European leaders met in 2017, still committed to the EU's motto of 'unity in diversity' but clearly with less enthusiasm, "to discuss the future role of education and culture in strengthening the sense of belonging together and being part of a cultural community" (European Commission, 2017b, p. 2). In contrast to framing a top-down transnational memory, an EU identity can indeed also be strengthened over time through education and culture, which then occurs in a more organic, bottom-up way. In addition to existing programmes, European leaders also outlined their "vision of a European Education Area, building on the New Skills Agenda for Europe and the investing in Europe's youth initiatives". The intention here is to make Europe's labour market more resilient and prepare the European workforce for "rapid and profound changes induced by the technological revolution and globalisation" (ibid, p. 2). It can also be seen as a way to encourage citizens to recognize that European political involvement has tangible benefits which would potentially make them view the EU, European institutions and hence European integration in a more positive light.

European institutions have been aware of their limited competencies in the area of education and culture as these "in line with the principle of subsidiarity" lie primarily "with Member States at national, regional and local level". Hence, "[t]he Union's competences are limited to encouraging cooperation, supporting and complementing national action" and the Union can continue to "finance programmes" such as the 
popular Erasmus programme in the space of education and media for cultural engagement (ibid, p. 2).

The raison d'être for education to be considered as a means of identity building stems from the fact that it "forms the basis for active citizenship and helps prevent populism, xenophobia and violent radicalisation". Culture is regarded as quintessential, as the continent's "cultural diversity is a strength that fuels creativity and innovation," together constituting "the European way of life". Both encourage people to engage in cross-border human connections and exchange which can lead to an awareness "of what it means to be 'European"'. Hence, "cultural heritage and diversity are prerequisites to maintain [Europe's] cultural community, [its] common values and identity" (ibid, p. 3).

In addition to actively promoting European citizenship, the European Parliament has analysed pathways for future political integration in Europe and raised the idea of a political compact as a means to create a more democratic and effective union. This idea took the form of "a Conference on the Future of Europe as a new model to reform the EU" which ideally "has the potential to be a transformative moment for the EU". Despite the delay caused by COVID-19, the current economic and health situation "revealed in an unequivocal way the need to overhaul the EU and to make it more effective and legitimate" (European Parliament, 2020, p. 10f). The Conference on the Future of Europe is now scheduled to run over the course of the next two years until 2022.

The conference faces one major roadblock on the path to further integration, namely EU treaty change. Reforms, as outlined in "the EU treaty amendment rule", require "the approval by all Member States meeting in an intergovernmental conference (IGC) and unanimous ratification at the national level". The rejection of the EU constitution exemplified the challenging nature of this clause. One pathway to circumvent obstacles associated with treaty change is to introduce international agreements that can be "concluded outside the EU legal order". Such agreements, with the potential to speed up the process, have been used in the past (European Parliament, 2020, p. 11). While any discussion on potential EU reforms would go beyond the scope of this article, the European Parliament is vocal about the necessity for a Conference on the Future of Europe as a much "needed initiative to reform the EU institutions and powers, to address important shortcomings in the EU governance system, and to chart a path towards further European integration after Brexit, and COVID” (European Parliament, 2020, p. 11).

All changes to the EU governance system have an impact on the EU's ability to introduce policies to strengthen an EU identity by supporting initiatives which enhance feelings of belonging and European citizenship in general. As outlined above, such initiatives can be of educational or cultural nature. Over the past decades, initiatives focused on a bottom-up approach to engaging citizens have led to better outcomes than those introducing a top-down European narrative on what EU identity is meant to be.

\section{Conclusion}

The EU has engaged with the issue of building an EU identity. This has met with only very modest levels of success with regard to top-down institutional nation-building. It 
has become visible when defining what EU (then referred to as European) identity was meant to imply with a shared narrative and in terms of civic engagement and a European sense of belonging. While a political union was created, it lacks the political identification of its EU citizens. Such political citizens rather grow as an emerging process due to education and culture from a bottom-up perspective over time and without the prescriptiveness of an institutionalised formation of what an EU identity is meant to be. Recent engagement of European institutions has focused on such an approach and included giving European citizens a voice in any EU reform in the form of civic engagement on the path of defining what the future of Europe can look like.

\section{References}

Berger, S., \& Lorenz, C. (Eds.). (2010). Nationalizing the Past: Historians as Nation Builders in Modern Europe. Basingstoke: Palgrave.

Borneman, J., \& Fowler, N. (1997). Europeanization. Annual Review of Anthropology, 26, 487-514.

Bruter, M. (2005). Citizens of Europe? The Emergence of a Mass European Identity. New York, United States: Palgrave Macmillian.

Castano, E. (2004). European Identity: A Social-Psychological Perspective. In R. K. Herrmann, T. Risse-Kappen, \& M. B. Brewer (Eds.), Transnational Identities: Becoming European in the EU (pp. 40-58). Lanham, USA: Rowmann \& Littlefield.

Cerutti, F., \& Rudolph, E. (Eds.). (2001). A Soul for Europe: On the Political and Cultural Identity of the Europeans. Leuven: Peeters.

Delanty, G. (2003, June). Is There a European Identity? Global Dialogue, 3-4, 76-86.

Delanty, G. (2019). Formations of European Modernity. Cham, Switzerland: Springer International Publishing.

Delanty, G. (2019). Formations of European Modernity - A Historical and Political Sociology of Europe. Cham, Switzerland: Palgrave Macmillan.

Eurobarometer. (2018, November). European Commission. Retrieved September 2nd, 2019, from Public Opinion:

https://ec.europa.eu/commfrontoffice/publicopinion/index.cfm/Chart/getChart/the meKy/26/groupKy/159

European Commission. (2012). The Development of European Identity / Identities:

Unfinished Business. Brussels: European Commission - Directorate General for Research \& Innovation.

European Commission. (2014). New Narrative for Europe. Cultural Committe for the "New Narrative for Europe" Project (pp. 1-4). Brussels: European Commission - Cultural Committee.

European Commission. (2017a). Horizon 2020 - Work Programme 2016-2017 - Europe in a changing world - inclusive, innovative and reflective Societies. Brussels: European Commission.

European Commission. (2017b). Strengthening European Identity through Education and Culture. Gothenburg, Sweden: European Commission. 
European Communities. (1973). Declaration on European Identity. Bulletin of the European Communities. 12, pp. 118-122. Luxembourg: Office for Official Publications of the European Communities.

European Parliament. (2020). Further Political Integration in Europe - A Political Compact for a More Democratic and Effective Union? Brussels: Directorate-General for Internal Policies - Policy Department for Citizens' Rights and Constitutional Affairs.

Habermas, J. (2009). Europe: The Faltering Project. Boston: Polity.

Kaiser, W. (2015). Clash of Cultures: Two Milieus in the European Union's 'A New Narrative for Europe' Project. Journal of Contemporary European Studies, 364-377.

Karlsson, I. (1999). How to define the European identity today and in the future? In T. Jansen, Reflections on European Identity (pp. 63-72). Brussels: European Commission.

Prutsch, M. (2017). Research for CULT Committee - European Identity. Directorate-General for Internal Policies, Policy Department for Structural and Cohesion Policies. Brussels: European Parliament.

Prutsch, M. (2020, June 26th). Senior Administrator, Directorate-General for Internal Policies of the Union, European Parliament. (J. Grimm, Interviewer)

Smith, A. (1992, January). National Identity and the Idea of European Unity. International Affairs, 68(1), 55-76.

Stanley, L. (2013). A European Supra-National Identity: The Solution to the European Union's Crisis of Legitimacy? London: The Bruges Group.

Stråth, B. (2002). A European Identity - To the Historical Limits of a Concept. European Journal of Social Theory, 387-401.

Tekiner, U. (2020, April 15). The ‘European (Union) Identity': An Overview. Retrieved 10 June, from E-International Relations: https://www.e-ir.info/2020/04/15/theeuropean-union-identity-an-overview/

Walkenhorst, H. (2009). The Conceptual Spectrum of European Identity - From Missing Link to Unnecessary Evil. Limerick Papers in Politics and Public Administration, 3, pp. 1-23. 